\title{
Cultural Integration of Turkish Immigrant Workers' Children into the Host Society An Intergenerational Comparison in the Context of France and Germany
}

\begin{abstract}
Kemal İnal ${ }^{1}$
Abstract

This paper aims to analyze the Turkish migration to Germany and France that resulted in a cultural integration through the emergence of second and third generation of children born in host society. To achieve this goal, a literature review of studies on the subject and the data produced in recent years were used. The paper was limited with the cases of Germany and France where most of Turkish immigrants still live and many recent studies and data on the subject were produced. The thesis of the study is that the migration of workers to two countries is a process of cultural insertion and social participation in modern society, in spite of the fact that it is an economic project. The immigrant taking a culturally distant position to the host society because of his/her different ethnic identity is firstly perceived as a foreigner, and submits in time to the integrative mechanisms of the modern system. At any rate, apart from the effort of defending his/her own original identity; the immigrant searches ways of integration to host society in the various levels and areas by forming many strategies and by using some means to achieve this aim. The settlement in the host society signifies the decision and desire of the migrant to take roots in the host society, and this is mainly to be realized through the child. The child who was born in the destination area causes the project of economic migration to be extended towards socio-cultural areas like education, since the future of immigrant's family is now entirely defined through the future of child with respect to the modern conditions. The expected success for their children in the educational and professional areas forces parents to leave from the traditional values and to internalize the modern ways of life. The modern values and attitudes of the second generational Turkish families towards their children in Germany and France indicate that the immigration is, first of all, a modernizing process. The study concludes that, comparing with traditional values, the Turkish parents describe their children in terms of the modern attitudes and conducts, pointing out the adaptation ability of immigrant's identity to the modern conditions.
\end{abstract}

Keywords: Emigration, Turkish Immigrant, Cultural Integration, Children of Turkish Immigrants.

\section{Avrupa'daki Türkiye'li Göçmen İșçi Çocuklarının Kültürel Entegrasyonu-Kușaklararası Bir Karșılaștırma}

\section{Öz}

$\mathrm{Bu}$ makale, Batı Avrupa'daki Türkiye kökenli göçmenlerin ev sahibi ülkelere olan kültürel entegrasyonunu ikinci ve üçüncü kuşakları temsil eden gençler ve çocuklar üzerinden, ilk kuşakla karşılaştırmalı biçimde analiz etmektedir. Bu çerçevede, alana ilişkin yakın yıllarda üretilen geniş bir literatür taraması yapılmıştır. Kullanılan verilerin büyük kısmı, göçmen Türkiyelilerin oran

1 Doç. Dr., Gazi Üniversitesi Illetişim Fakültesi. 
olarak en çok temsil edildiği iki ülkeyle (Almanya ve Fransa) sınırlandırılmıştır. Makalenin temel tezi, göçmen işçilerin çocuklarının yıllar içinde kaçınılmaz biçimde ev sahibi topluma kültürel entegrasyonunun olacağını ileri sürmekte, bunu da ikinci ve üçüncü kuşakların birinci kuşağa gore aldığı modern pozisyona göre değerlendirmektedir. Haliyle, başta ekonomik bir proje olan göç, sonraki kuşaklarda kültürel ve sosyal bir proje haline gelmekte, göçmenlik koşulları zaman içinde ev sahibi toplumda kendini oranın değerleriyle ifade etmeye dönüşmektedir. "Göçmen", "yabancı" ve "öteki" kategorileri, "yurttaşlık hakları" elde edildikçe, kurumlarla (bilhassa ikinci ve üçüncü kuşak için eğitimle) bütünleşildikçe giderek zayıflamaktadır. Avrupa'da doğan veya büyüyen Türkiye kökenli çocukların eğitsel ve ekonomik gelecekleri, birinci kuşağı modernleşmeye yönelik bir tutum almaya zorlamaktadır. Böylece modern değerlerin dikkate alınmasında geleneksel bazı değerler de zayıflamaktadır. Fakat elbette bu süreç, düz ve sorunsuz bir biçimde olmamakta, 11 Eylül gibi olaylar sonucu bu entegrasyon süreci, yabancı düşmanlığı gibi nedenlerle yavaşlayabilmektedir.

Anahtar Kelimeler: Göç, Türkiye Kökenli Göçmen, Kültürel Entegrasyon, Türkiye kökenli Çocuklar. 


\section{Introduction}

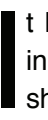
t has been almost half a century for Turkish labor force as immigrants who officially arrived in Europe. In fact, their migration was mainly based on economic reasons. After a relatively short period they would have gone back to homeland with the aim of having an affluent life for themselves. But they changed their decisions in a few years because of secular and modern life conditions presented to them in Europe, firstly in Germany and then in other countries such as Germany, France, Austria, Holland etc. Now some millions of Turkish immigrants in Europe describe themselves as not immigrant or guest worker, but citizens having several rights (voting etc.) like host population. Considering themselves as an integrated part of settled population in developed regions of European countries, Turkish immigrants formed in this period an originally parallel community nearby host people, in spite of the fact that they have some expectations and relationships with Turkey such as the desire to return to the homeland, investment, and some cultural and political engagements. This parallel community, even if it was established in the interaction with motherland, has some specific characteristics. One of these characteristics is related to integration, adjustment and adaptation problems occurring amongst the generations. The first comers finished their working life and gained the right of retirement. For this part of Turkish population in Europe there were no expectations towards the social promotion and the desire to integrate into the European community, but on the contrary, the subsequent generations have fairly different goals and expectations since they either came or attended to the school after the first generation, or born in Europe. So due largely to their educational background and heavy socio-cultural relations with host young people, they absorbed some modern values that were very different from those their parents had.

The main aim of this paper is to research the Turkish migration to some Western countries (Germany and France) that resulted in a cultural integration through the emergence of second and third generation of children born in host society. The research subject is on the ability of Turkish immigrant workers' and their children's cultural integration into the host society, pointing out that the immigrant suits in time to the integrative mechanisms of the modern system of the destination area. This study argues that Turkish immigrant population searches the different ways of integration into host society where their children were born and their future are heavily and firstly considered by their parents. The article looks especially at the cultural dimension relevant to the changes and differences appearing among generations. The cultural integration of Turkish immigrant workers' children into the host society is described by making an intergenerational comparison in the context of Germany and France.

The main question of the study is that why the migration project is in time considered by (Turkish) immigrants as a cultural integration process, in spite of the fact that all migration decisions at the beginning were taken at an economic dimension. The study aims to demonstrate why immigrants' children born in the host society force Turkish parent to find the most suitable solutions for the sake of their children's future in Western Europe. To realize the aim of the study, the related literature is reviewed, and some data and views on Turkish immigrants in Germany and France are compared to show some differences in two countries. This study contributes to the literature in the following way: So far the Turkish immigrants were always mentioned at the context of the concept of cultural maladjustment. But this is true only for the first, very traditional generation. However, children of Turkish immigrants, namely the second and third generations have now the ability and formation to acquire some modern attitudes in many areas. This study stresses that the cultural dimension of the migration should be taken into account as well as economic dimension. 


\section{Theoretical Discussion}

\subsection{Migration as a Cultural Fact}

The last century was described as "the age of migration" (Castles and Miller, 1993). As a natural state of humankind (Somersan, 2004: 151) this modern process was defined by many social researchers, and the term immigration has been generally interpreted in both local and sociocultural contexts. For Stillwell and Congdon migration is a change of usual residence of a person, family or household, so it is inherently geographical because a change of residence necessitates a movement from one location to another (Stillwell and Congdon, 1991: 3). As a fundamental feature of human societies today and over varying distances and on a range of timescales (Pooley and Whyte, 1991: 1) migration is a very decisive fact for all humankind, but especially for the poor migrants today moving to the Western countries. For Kosinski and Prothero, when it is preferable for the poor to move rather than to stay at home and to gain the expected rewards, the migration takes place despite all the difficulties (Kosinski ve Prothero, 1975). Thus individuals seeking a secure life through migration are characterized "by aspiration to better their economic position by acquiring needed skills and efficiency" (Henslin, 2001: 581; Sinha and Ataullah, 1987: 163 ) and to improve the prospects for their children (Richmond, 1988:11). This is the main logic of contemporary migration movements towards the West, meaning to have economic advantages and expectation of social promotion in the host country. So, as put forward by Verbunt (1977: 8-9), because the main motivation of the migration is to improve the economical status, the cultural prospects are secondary to the immigrant. The migration project is to have an economic power which will bring money and privilege in the future. There is very little place for cultural autonomy in such a project. For an immigrant, cultural life will be a function of the realization of economic project.

However the decision to move to a culturally very different space, namely to the West, has many social implications and cultural meanings for immigrants, especially for second and subsequent generations born or trained in the destination area and living at the heart of the integration and adjustment problems. This shows us that migration today must be interpreted not only in the framework of economic aspirations but also with the modern aspects of cultural conditions since the decision to emigrate for an individual or a family to any location culturally very different from the homeland means to be subjected to the acculturation effects of the host population. Then, migration is not solely a movement of labor force but also one of traditions and beliefs (Naïr, 1990: 49). It gives rise to some cultural interactions with native or host people in the immigrants' lives in the long term. It involves a social or cultural change in the life of the migrant and is "regarded as a cultural experience rather than as a purely spatial or temporal event" (Boyle et al. 1998: 37). It is both a reflection of and a constitutive element of culture, and a key practice in people's lives (Boyle et al. 1998: 207). This fact means that "migration tends to expose one's personality; it expresses one's loyalties and reveals one's values and attachments (often previously hidden). It is a statement of an individual's world-view, and is, therefore, an extremely cultural event" (Fielding, 1992: 201). As a result, “...migration can form a crucial component of people's maps of meaning" (Boyle et al. 1998: 234) in which all migrants seek to find their main way to solve the problems originating from the spatial and social change. In other words, migrating to the city gives rise to all by itself some social changes, resulting in the behavior and value changes of the immigrants' cultural world (Kağıtçıbaşı, 1981: 41). Having a potential to change the traditional cultural structures, it "could also be envisaged as instrumental in the creation of new cultures and in altering the relationships (such as those of dominance and subordination) between existing cultures in particular places" (Fielding, 1992: 203). Consequently, migration gives rise too many 
changes due to the modern socio-economic conditions presented by the host society, but these changes or transformations are also affected by the cultures of newcomers since as pointed out by Fielding, "....migrants are the 'bearers of cultural practices.' As such, they sometimes sustain, but more often alter, the balance of cultures in the origin and destination regions" (Fielding, 1992: 207). This assumes that migrants constitute an active population in the post-industrial society. As argued by Fielding (1992: 206) migration, if a spatial movement "to a place which is rich in opportunities to socialize, can then be experienced as a process of joining in, engaging with others, losing one's isolation." Maintenance and reinforcement of cultural identity or the original culture by the first generation can be discussed undoubtedly as an inevitable fact in which the migration presents all the possibilities of change. These changes variously affect the immigrants with respect to the different factors such as the level of income and education, social status, the place of birth, language and religion.

The economic-oriented emigration of poor labor is not only in fact a modernization process to know socio-culturally "the other", namely citizens of western countries, but a social mobility project which enables the immigrants to get the means of participation into the modern society. Migration can encourage the cultural participation into the modernity (Schnapper, 1991: 95, 169), because immigrants can get the new and modern information on income strategies, consumption habits and social organizations in the destination place (Şen ve Koray, 1993: 9). Therefore, as a transformation and readjustment project immigration is not a one-sided or a simple process, but includes many complex and mixed relations from the point of both the host and immigrant populations. The cultures encountering in the end of the migration process can influence each other; the components belonging to the modernity and the traditional culture of immigrants can be mixed to form a new synthesis (Schnapper, 1991: 162; Kastoryano, 1986: 133).

\subsection{Adjustment, Adaptation and Integration Models On Migration}

Before the term integration, we need to explore the models of integration. There are mainly three adjustment models in the literature on migration: assimilation, melting pot and cultural pluralism. As a model developed and formulated by Robert Park, assimilation is a process by which immigrants adopt the cultural norms and lifestyles of the dominant culture, resulting in a gradual process of change in the minority group (and not in the receiving society) gives rise to the immigrants to abandon their culture of origin in order to adapt themselves to the host society (Carmon, 1996: 23). Richmond (1988: 110) argues that immigrants from particular countries can eventually form some degree of social cohesion and find their own separate institutions and organizations to react against to the discriminatory treatment by the receiving society. However, "today more than ever it is important to recognize the polytechnic and culturally diversified character of both sending and receiving countries. There is no single 'American way of life' into which immigrants arriving in the United States must eventually be assimilated. The United States are ethnically stratified, culturally pluralistic and exhibits a diversity of life-styles" (Richmond, 1988: 109-110). It is argued that through assimilation cultural and linguistic differences disappear leaving a symbolic ethnicity (UN, 1994: 43).

As the title of a new and the best model of integration which was firstly formulated until the 1940s by the American researchers, America was considered as the great melting pot for all the races of Europe to be reshaped (Carmon, 1996: 23). But at the beginnings of 1970 s sociologists, by using recent data, began to insist on that American society was not a melting pot (Somersan, 2004: 91). For those who occupy "a subordinate position in the segmented labor markets of individual societies" and concentrate "in low-status areas as well as widespread prejudice and 
discrimination from the indigenous population" the thesis of 'melting pot' is "fundamentally an alien concept" (Köksal, 1991: 98). The model of cultural pluralism was regarded that the different groups of society can influence each other reciprocally, that they together can create the national space in which "all participants are citizens with equal rights and with which all of them identify. The goal of the integration process was redefined as promoting civic unity while protecting ethnic diversity" (Carmon, 1996: 23-24). But this term is also open to many criticisms if the developments after the September 11 events in USA and other countries are considered.

Many commentators argued that all three models were incomplete. The model of assimilation, which was considered to be the best result for both the host society and the newcomers in America, is no longer accepted by those who favor the protection of the immigrants' original cultures. Richmond (1988: 109) describes this term from the point of some changes:

Earlier sociological studies of the assimilation of immigrants were often based upon an oversimplified misrepresentation of the characteristics of migrants and the conditions in sending and receiving societies. In the nineteenth and early parts of the twentieth century, waves of immigration to North America and other areas of the New World largely consisted of poorly educated peasants who entered countries that were themselves experiencing all the upheavals associated with the early stages of urbanization and industrialization. The problems of socio-cultural adaptation experienced by such immigrants were quite different from those whose international movements have taken place in the age of jet aircraft, radios, telephones, television and computers. Even in the earlier era it was not appropriate to treat the migrants as uniformly of peasant origin. At the same time the receiving societies themselves were not always culturally homogeneous or monistic.

As pointed out by Lapeyronnie (1993: 22), the term assimilation is rejected since it is associated with the colonialist past of France. By constructing an opposition between assimilation and integration the discussion took a very ideological course in Western countries. Therefore, today the integration is the term that is widely accepted, instead of assimilation that has an image which is not progressive, since it is defined as a reduction and absorption of cultural senilities and comportments of the migrants (Tribalat, 1995: 12-13). Social researchers today insist that "the culture of the immigrant should be left intact... They think that the immigrants should be allowed or aided to keep their old "roots" in the culture of the alien soil from which they departed, that their offspring should be educated in their "mother-tongue" and not in the language of the society to which they have come ... they should be allowed and aided to retain the culture which they acquired and possessed in their place of origin" (Stolnitz, 1978: 407). As mentioned by Carmon (1996: 24), "all three models take a macro view point of the receiving society. They ignore the possibility that the process of immigrant integration can take different forms in different parts of the society (geographically and socially) or where it relates to different types of immigrants. They also ignore the wishes of the immigrants themselves as determinants of their integration or nonintegration. The present behavior of immigrants in various developed countries indicates that disregarding their motivation is "a mistake." The immigrants can bring their traditional cultures to the host society and search to find the new synthesis. This search for new cultural synthesis is in fact the very modern way of expressing their desire in favor of integration in the host society. For this reason, many scholars today prefer to use such terms such as "integration", "adjustment", "adaptation" rather than the concepts mentioned above. 
Integration means "arrangements which enable immigrants and minorities to participate in all aspects of the host society... Successful integration depends upon equality of individual opportunity within the whole society, free of discrimination on grounds of origin" (UN, 1994: 43). Adjustment, the process by which immigrants adjust themselves to conditions in the host society, is not "...necessarily a one-way acceptance of the norms and values of the receiving country. Migrants bring different values to their new environment, and the question of mutual adjustment or feedback should not be overlooked" (Macisso, Jr. 1992: 238). "For emigrants... the term adaptation is used to mean adjustment or re-adjustment into a new 'physical or social environment'. It involves re-socialization with a view to facilitating interaction with the dominant group or with the dominant culture" (Lingayah, 1991: 40).

As stated by Lewis (1982: 31) "[t]here are various social, economic and political forces, or adjustment mechanisms, which play a significant role in the process of a migrant's transformation. The act of migration sets in motion a series of adjustments both in the village and the city", in which the migrants can sometimes take the leading role. "When a person migrates to the city, he is faced with the challenge of mobility within the new setting. This mobility may require a new life style, new attitudes, and new behavioral forms. Just as the migrant has been socialized into his rural life ways, so he now must learn the new social structure of the city" (Hanson and Simmens, 1968: 152-158). So, migrants are changed as they adapt to the city (Du Toit, 1975: 12). The immigrants invent and use various adjustment and integration means in the process of heavy and hard struggle to meet the demands required by the host country. Thus, they develop different strategies and can find solutions for the integration problems, such as investing in various ethnic businesses, desiring for social ascension, and schooling of children, struggling for economic rights and political participation, buying real estates, and establishing and attending to social organizations for the immigrants. All these can be interpreted as a search for adjustment, adaptation and integration in the host society.

\section{Discussion and Arguments}

\subsection{Migration in the Western Europe and Composition of Turkish Immigrant Workers}

After the World War II, with the decision of some Western industrialized countries, which were in difficulty to find the necessary labor power to strengthen their economies, a massive migration movement from some Mediterranean countries like Spain, Greece, Yugoslavia, and Turkey to the Western European countries such as Federal Germany, France, and the others had been one of the most important agendas of many interested agencies (Bazin, 1994: 90; Abadan-Unat, 1978: 1). The main motivation of the Turkish labor at the beginning of the migration movement was the economic. Their only goal was to work throughout a few years, to save more money as possible to be able to improve their conditions of life and so to get a certain social status upon returning to Turkey (Öztürk, 1995: 241). Migration of the workers to Europe was considered by Turkish government as a 'demographic solution' to the economic (employment, scarcity of foreign money, etc.) and developmental problems (training of adult labor power in the foreign countries, modernizing the homeland by the workers' return etc.) (Abadan-Unat, 2002: XIX; Küçükkaraca, 1998: 23). Therefore, "migrants were encouraged to fill temporary labour gaps, by staying for a few years and then leaving again" (Lewis, 1982: 36).

The Turkish immigration of labor which started at the beginning of 1960 s affected heavily some European countries in many ways. Amongst these countries, France was one of the many countries where Turkish workers were the settled immigrant population. With the need for the 
labor power after the Industrial Revolution, France like some other European countries also became a migration country. By the end of 1990s the proportion of the foreign people in the French population increased to $7.3 \%$, which were approximately 4,200,000 people (Farine, 1999: 97- 99). The migration of Turkish labor power to France started in 1960s and this movement became intense after 1967. The main objective of the many Turkish immigrants till 1970 was to establish a financially secure life after returning to homeland by saving sufficient money. However, after 1970 s the duration of staying abroad began to be extended by Turkish immigrants. So the plans to return to the homeland tended gradually to be uncertain and to be delayed (Sertel, 1987: 24). Because of this reason migration having an economic motivation in the beginning became a migration of settlement, peuplement (Schnapper, 1991: 173). After 1975 the Turkish immigrant workers moved their children to France, with the aim of utilizing the allocation of family and child care in France (Abadan-Unat, 2002: 190).

With the decision of settlement in foreign countries, approximately 5 million Turks today live in 5 different continents, mainly in the Western Europe ( $86 \%$ of them are in Germany). The rate of Turkish immigrant workers including those having double citizenship in France increased to 360,000 in 2003 . The majority of this population consists of younger generations. According to the population census in 1999 in France, the proportion of Turkish children of 14 years old or younger is $25 \%$; the share of those of between 15 and 24 years old is $25 \%$ (Republic of Turkey, Ministry of Labor and Security, 2004: 109-110). In Western Europe, where 3 million immigrant Turks live, one million of Turks are 19 years old or younger (Arayıcı, 1998: 129). The Turkish immigrant population in France is also very young as is the case in other countries (Irtis-Dabbagh, 2003; Tabouret-Keller and Konuk, 1996; Salom, 1989). Thus, it is reasonable to state that "...the emergence of a second and even a third generation of immigrants have considerably altered the demographic picture in a number of developed countries" (Le Bras, 1991: 15). Accordingly, the foreign immigrant population in France is younger than the native people (Frybès, 1992: 85). It was argued that the largely young immigrants which either came by means of family union (le regroupement familial) or were born in France broke the ageing of French population and had an impact of rejeunissement on the native people (Taïeb, 1998: 144; Blanc-Chaléard, 2001: 80). However, although it is a fact that "immigrant women generally tend to have a higher fertility rate than indigenous women..." (Le Bras, 1991: 25-26) and "...foreign fertility is still higher today than that of nationals in many countries" (OECD, 1991: 40) the birth rate of immigrant Turkish women in France has the tendency to decrease after the migration (De Tapia, 2004: 8).

\subsection{Arguments on Cultural Integration of Turkish Immigrant Workers}

Today the term integration in the Western Europe became the essential word, (le maître mot) related to the discourses (Helle, 2004:31). In this context many different arguments on immigrants, especially for the Turkish and Arabic workers living in Western European countries have been put forward to describe the recent developments on integration.

It can be argued that there exist two opposite views on the adjustment, adaptation and integration of Turkish immigrant workers to the host society. For scholars in favor of the negative view, the Turkish immigrant workers, at least for those who comprise the first generation, did not change their socio-cultural position by defending their conservative traditional cultures in order to protect their original identity. On the other hand, those favoring the positive thesis claim that the migration is a process including a potential of change, influencing both sides since integration insists on itself in time as a norm. Former scholars put forward various comments and data connected with the unsuccessful adjustment, adaptation and integration of Turkish immigrant community to the 
host society in Europe. It is argued that the Turkish parents live in ghetto-like dwellings, isolated from modern European's modern life style (Abadan-Unat, 1976: 12; Abadan-Unat, 2002: 181; Sertel, 1987: 129), and cannot engage in a satisfactory level of relations with the native people. Their tendency and level of interactions with natives is very insufficient (Kastoryano, 1986: 39, 52; Unbehaun, 1995: 159; Mutlu and Sancar; 2000: 236-237). Their educational level is very low (Pieters, 2005: 261), and they do not adequately try to learn European languages (Sayın, 1975: 166-167). They know little or nothing about their lawful responsibilities in the host country about the schooling of their offspring, and this lack of knowledge keeps many young migrants out of school (Bilmen, 1976: 243). As a result, inadequate language training gives rise to poor elementary and secondary performance, resulting in higher drop-out rates (Mushaben, 1985: 140). They marry off their daughters in the very early ages by restricting their liberties (DPT, 2001:20; Mushaben, 1985: 142-3). They demand their children to earn their living as soon as possible to help family budget (DPT, 2001: 20). Their children live within a universe of crisis and a blurry identity (Salom, 1995: 255). Very strong cultural conflicts among generations take place (DPT, 2001: 20). The first generation lives in an isolated world very different from the native population, and see the Islamic religion as a cultural identity and a way of belonging to the community (Kastoryano, 1991: 116), and their only model of reference is based on Turkish identity (Salom, 1989: 148).

It was claimed that the living conditions of women belonging to the first generation are worse than their husbands. The proportion of illiterate women is very high, namely some $80 \%$. As pointed out by Salom (1995: 253) these women live as if within their village in the heart of the French city. They could not reconcile their culture of origin and way of life in the West. They become increasingly estranged from their children who speak an alien language and sing songs which they don't know (Manço, 1996: 168). The language barrier hinders mothers from helping their children with their school work or establishing contact with their schools, and from transmitting adequately the cultural heritage of the home country (Kadıoğlu, 1990: 83-84; Kağıtçıbaşı, 1985: 118). The immigrant Turkish women have therefore nothing within their valises than rural traditions, familial customs and educational values transmitted by their mothers (Hüküm, 1996: 181). It seems that the only possible way for mothers in training of their children is to inculcate them with the traditional values such as shame, sin, and honor of family. It is a natural fact that the women experience these sorts of problems caused by the immigration since, as explained by Abadan-Unat (1982: 214) "migration has a more positive effect on men than it does on women. Female migrants experience lower occupational status, longer working hours, lower earnings and worse living conditions. Discriminatory practices are bound to affect women migrants because they are restricted from the outset in terms of opportunities, types of work, and work conditions available to them." Because of this hard operating process for women and the rapid transition from the traditional way of life to the industrial conditions, they face many psychological problems such as "uprootedness syndrome", "atypical depression", "neurosis", "depressive reactions" and "nostalgia reaction" in addition to the physical symptoms such heart or chest pains, stomach ulcers, sleeplessness, lack of appetite, physical deficiency, sexual problems, and head and back aches (Abadan-Unat, 1982: 221). These kinds of problems leading to the severing of social ties and some anxiety were related with the adjustment to an unfamiliar environment (Richmond, 1988: 112).

No doubt and needless to say, the views mentioned above have a definite share of truth. In fact, the mechanism of social control used by the immigrant Turks in Europe reinforces the norms belonging to the original culture for the first generation (Manço, 1996: 165). These norms function as a mechanism of social pressure on the children (Akkaya, no date: 92). In addition, the level of social control of the community on the second and subsequent generations is much more severe 
in Europe than in Turkey (Camilleri, 1996: 189), and this control gives rise to the loss of original identity (Kastoryano, 1986: 67). It was expressed that the gathering of the immigrant Turks in the same neighborhoods causes to empower the traditional solidarity relations; as a result of this fact, the traditional culture can be transmitted to the younger generations by giving rise to the protection of the traditionalist ideologies (Kastoryano, 1994: 99-100). Among these ideologies, Islam as a "familial cement" (Groc, 1995: 263) and "protector of the identity" (Caymaz, 2002: 30) push the Turkish parents towards the religious discipline which is one of the principal means of sociability aiming at total obedience of the school children to the Koranic educators (Caymaz, 2002: 160).

These sorts of arguments are true but of course valid only for the workers belonging to the first generation. Despite of 45 years for the first workers to be spent in the exile (gurbet in Turkish), the adjustment and integration problems of this generation could not be solved since "it does not necessarily follow, therefore, that the level of assimilation, adaptation and integration are simply a function of the amount of time spent living in a particular place. There are many cases where people have lived away from their home areas for five or six decades and yet have not managed to pick up the language or dialect which is spoken in the destination area. Such a situation tends to be more noticeable amongst the older generations, who may be more set in their ways and may find it rather difficult to change the habits of a lifetime" (Parnwell, 1993: 125).

It can be supposed that there are many factors affecting this unsuccessful duration in the destination area: insufficient integration policy of European governments, the segregating attitudes of the native people towards the migrants etc. Apart from these negative factors, it is a fact that the cultural, educational and economic baggage/capital of the first comers to Europe belonged to the underdeveloped regions in Turkey. As stated by Stolnitz (1978: 414) "the immigrants to the European countries are, in the main, from the poorest classes of their own societies. Frequently peasants or agricultural laborers who lived in hierarchical societies, usually in villages and in large families under strict paternal and elderly authority which demanded deference to and observance of religious beliefs, they were only slightly educated in the higher culture of their respective societies". Many researches were conducted on the first comers proved that majority of them were people who were either poor peasants or unqualified workers having a low level of education and income (Sertel, 1987: 152; Yılmaz, 2001: 32; ArayıCI, 1998: 58-60). However, transformation of the traditional culture is begun to be realized with the birth and the time of schooling of the new generations. Some factors such as the material conditions of the family and experiences of the children put pressure on the parents to change their traditional habits in favor of their offspring. The other variables such as the quality of dwelling unit, the level of income and education, occupational position, the search for modern life, getting high expectations etc. force the parents to enter a new world which is very profitable for the future of their children.

As claimed by Abadan-Unat (1982: 226) "migration imbues participants with an increased awareness of change." So in the context of intergenerational transformation, researchers observe some positive changes related to the Turkish immigrant families. To illustrate, Turkish immigrant families in Western Europe, especially those belonging to the second and third generations, began to be employed in more qualified jobs and to establish their own works ${ }^{2^{*}}$ (Brabant and Levallois, 1995: 196; Kleff, 1995: 168), buy real properties (Abadan-Unat, 2002:323), demand complete civic rights (Kastoryano, 2000: 21), obtain the citizenship of the host country (Manço, 1996: 166), and marry with the native people and let the women enter to the labor markets (Kançal, 1995: 145). In addition to these, it is observed that the demand for integration into the consumption society 
has been continuously increasing (ASTTU, 1995: 7). They started to learn the language of their host country and attend to the sport clubs. The rate of schooling is also increasing (Manço, 1996: 166). For them the trend of coming back to motherland is fairly and continuously disappearing (Şen and Koray, 1993: 41) and the decision in favor of staying permanently abroad is made (Zarif et al. 1995: 14). All these considerations on recent developments related to the immigrants can be discussed as the indicators of the transformation of the Turkish families at the context of migration; especially this is true for the second and third generations. In comparison with the first generation, "the younger generations may more readily become assimilated on account of their greater receptiveness to change, and also because they have more opportunity to come into contact with members of the host society at school or in the workplace. The demands of education and employment make it imperative that they should be able to communicate and interact freely with members of the host society" (Parnwell, 1993: 126).

Several factors such as social development, the tendency to establish own business, the desire for schooling of children cause to make the decision to delay the return plan. Finally, the first Turkish generation in Europe attained the age of retirement and continuously needed to benefit from the modern health service of Europe (Zarif, et al. 1995: 14). As argued in the findings in all the researches on this issue, the Turkish workers from rural areas of Turkey, who migrated to Europe due to the economic reasons (Paine, 1974: 87) had a strong desire for social ascension and an aim of gaining respect in his/her neighborhood (Kastoryano, 1986: 16). So the migration to Europe in the beginning was shown by the first generation as a temporary stage.

The first Turkish immigrants in Europe had seen themselves as "expatrie" ("gurbetçi" in Turkish) and were ready to accept the position of "guest worker" (Gasterbeiter) The term "expatrie" defining the temporary phase for the first generation today has no any meaning for young Turks, especially for the second and third generations in Western Europe. Some material developments such as retirement in Europe, buying the real estate, investment in economic area, involvement in political life etc. were interpreted by some commentators mentioned above as the inclination to become rooted and to be integrated in Europe. This is surely an important result of social transformation occurred among the generations, that means the desire for modernization in Europe.

\subsection{The Differences among the Generations with Respect to the Cultural Integration}

The concept of "generation" indicating a social unit and assuming certain homogeneity of this unit in the migration literature means the difference of life, (la différence de vécu) between the parents and their children. There is a definite difference in the historical experiences and motivations of the generations since each generation participates into the host society in different moments and historical contexts of life circle (Wilpert, 1996: 120-121). As a result, the new generations have very different experiences in comparison with the preceding and are heavily subjected to the new, postmodern values. However the cultural relationships among generations can be very problematic. In the process of transmitting the original culture and native identity to the children, "the older generation mourns the infidelity of the new generation to the parochial traditional culture in which it was "rooted"... Meanwhile, the new generation renounces something which it scarcely values and acquires something, the value of which is uncertain ... The new generation is left hanging "between the cut and dried" of the roots taken out of the place in which they grew and the "here and now" of a more powerful society. They do not have to renounce it all, and indeed they cannot" said Stolnitz (1978: 147). Hence the first generation establishes the organizations to teach the mother tongue and to transmit the original culture to their children, and organizes festivals and carries out rituals (Castles and Miller, 1993: 222). "First generation immigrants 
may not mind being at the bottom of the economic ladder, but their second and third generation children are likely to have the same aspirations as native children" (Martin, 1996: 33). Despite of this, "the assimilation of the culture of the host society by the offspring of immigrants can never be complete because they cannot lose all of the culture of their ancestors. They might in the second generation, at least for a time, be ashamed of this, but the fact is that they do retain some of old culture" (Stolnitz, 1978: 422). However much the second and third generations internalize some traditional values of their parents such as mother tongue, traditional food, and religion; they are largely subjected to a good deal of effects of adjustment and integration in the host society.

So it was pointed out by some scholars that younger Turks are much more professionally advanced, socially flexible, and culturally well-adjusted in comparison with their parents in Europe and that the integration problems of the second and third generations have been gradually disappearing and thanks to this development they attempt to play new roles in the host society (Vassaf, 2002: 293; Akkaya, no date: 73; Şen et al. 1996: 22; Zarif et al.1995: 16; Arayıcı, 1998: 61; Berksu, 1999: 1). In addition, the expectation for social ascension and a powerful desire to attain a privileged social status in the host society are spreading out among younger Turkish population in Europe as epidemic (Akkaya, no date: 114). The second generation now focuses its attention and energy on professional training, and on the contrary to their parents, wants to work as qualified labor force and to be employed as government officials by climbing the social ladder (Mushaben, 1985: 142; Şen, 1990: 11). For the second generation there are no conservative attitudes, contrary to their parents (Gül, 2002: 63), and while the first generation is still heavily interested in the oral or expat literature like folk songs in which the local singers express the powerful desire for homeland and the returning plans, the second and subsequent generations are curious about the modern Western literature and rap music with Turkish words (Öztürk, 2002: 93-94; Greve, 2006: 37-50). Abadan-Unat (2002: 182-3) describes the process of change among the generations as below:

The first generation of Turkish immigrants didn't aim at being a part of the host society. In spite of the fact that they had a low status in the host society, the Turkish immigrants supposed a higher social position compared to the conditions in motherland. However, those belonging to the second and third generations born in host society compare their positions to those who are from the same age group and perceive severely some opportunities and possibilities from which they are deprived of. So it attracts attention a difference in the form of comportments of the first and second generations. The first generation is interested in the myth of return, tries to get esteem via consumption as a neo-feudal adaptation, and so turns towards collective identity. There are some different alternatives for the second generation. They can choose partial or total assimilation, or can reject through aggressiveness or withdrawal via apathy. The milieu where the young are located also determines the cultural identity they will accept.

The cultural and political connections and concerns of the younger generation about Turkey are getting weakened while this process transforms the Turkish community into one of Europe's permanent population (Kızılocak, 1996: 16). Younger Turks make much more contacts with the native population than their parents do, and prefer to marry with Europeans. They do not want to work anymore in the occupations regarded by their parents as worthy. 
However it will be a mistake to argue that the younger generations can integrate into the host society without problems (Schultze, 1995: 152). Migration causes some negative effects such as increase in divorce rates, decline of the mother's authority on the children and the cultural shock both on family life and the status of women which may be positive as well (Abadan-Unat, 2002:152).

\subsection{The Challenges of Integration and New Problems of Younger Generations}

Living in new but unusual conditions after September 11, 2001 in USA caused many problems for elderly and younger Turkish generations living in Western Europe as well as Muslim population from very Islamist countries at Middle East and Northern Africa. After this date, significant increases in the rates of discrimination, racism and xenophobia ${ }^{3}$ occurred all over the Europe (Koç, 2009). This event was a new barrier in front of the integration claims for migrant population, that means an away from the idea of multiculturalism. Needles to say, claims for a multicultural democratic society in European countries did not prevent xenophobia that is accompanied with structural problems. For instance, the rate of unemployment is the highest amongst younger people of immigrant parents, which exacerbates the cultural stereotypes about immigrants. Various cultural prejudices against the immigrants lead to very conservative attitudes for some part of younger generations who choose to express themselves in Turkish nationalist and Islamist identities and vote for conservative Turkish current ruling political party of Justice and Development.

In addition, on the one hand, the decision of some of younger Islamists' involvement in ISIS as alien fighters was used by the extremist right in Europe as an opportunity against the idea and policies of multicultural and integrated Europe. On the other hand, elderly migrants still have a potential to affect the young in the Islamist and nationalist ways. It is a fact that there are many elderly Turks in Europe supporting and voting rightist politicians in Turkey. This can produce reactionary individual or communal attitudes and actions against migrants. It means that the young people in Europe is now living under much more pressures of discrimination and prejudices when compared with the previous period. For example, in Germany as well as France, young people could not attend even the highest levels of education and working markets since many of them can not get a chance in attending to the college or university or climbing to the top position in working places due to the some reasons (Buz, 2008; Schittenhelm, 2011). Even though this is a fact and needs to be overcome by European countries, one can not find sufficient policy and practice all over Europe in order to solve this urgent difficulty. This leads significant proportion of host population believe that low level of intelligence, information and language skills of immigrants' children is the proof and indicator in failure of integration. So they think that the immigrants must come back to their countries because of this failure that cause to get a low level of national education in international education test scores.

But this extremist rightist look at the immigration and integration can not solve any difficulties of immigrants since everyone should accept that Europe is still in need for the younger generations as labor force, cultural richness and an idea for coexistence as both culturally and politically. One can find many positive younger exemplary figures that are seen as indicators for solutions in integration process. The only way in front of the host country as well as immigrants is to coexist in a multicultural democratic society where cultures and political tendencies of immigrants should be taken into account as indispensable part of that culture and politics. Many factors such as

3 Islamophobia may be accepted as the most common form of xenophobia in Europe, that manifest itself in many ways such as when seeking a jop or in orientation programs in schools for younger students of immigrant parents. See for detail information: Aydın and Yardım (2008). 
the unending process of immigration, globalization and the widespread demand for democracy present new conditions for the host countries as well as immigrants who are in search of secure living places. Europe has any more a new situation where the so-called "alien" population do not see themselves in fact as guest, migrant or temporary people. The immigrants began to adopt European countries as their second home. In this regard, there are many recent developments in terms of political participation, schooling, and cultural integration. Third generation is very different from the first one. For instance, significant proportion of first Turkish immigrants in Belgium was illiterate whereas the third generation deviates from the previous ones with a higher rate of university graduates (Cakirek and West, 2009: 72). In addition, after the coup of September 12, 1980 in Turkey, many well-educated Turkish and Kurdish young people had to migrate to Europe as politic refugees or exiles who tried to integrate into host society by taking some roles in European politics. In a very new research on Turkish and Kurdish refugees living in England, we see that refugees originated from Turkey represent negotiating new forms of identities in a host society. They are very active agents, saying that they construct and re-construct their identities by making individual as well as communal decisions in maintaining their ties with host country's culture as well as some cultural elements of their own community. They, especially second generation, experience double socialization in these distinct cultures (Erdoğan, 2009: 378-379). The decisions for many collective actions such as marrying with European man or woman, setting up a business with host people together and political involvement in European political parties and local government at the various positions, all these create new opportunities for younger generation in living a multicultural democratic society since it functions positively among the host and immigrant people.

\section{Conclusion}

The issue of how immigrant Turks in Europe will be defined from the point of identity is not yet obvious among Turkish social scientists. While some consider them as "Euro-Turk" (Kaya ve Kentel, 2005: 1-161), some others call them as "the Turks in Europe" (Atay, 2006: 15). These kinds of definitions do not have any practical importance since the descendants of the first immigrant parents in Europe feel that they belong to Europe where they were born and educated. But it can be claimed that the new, especially the second and third generations pass from a hard adaptation and integration process. In spite of the fact that in this process the younger generations are confronted by various tensions and conflicts; new generations, especially children or young people need to participate in many areas of modern social life much more than their parents do. In the participation process some problems related with identity, culture, language, religion, family and customs can be considered as natural tensions and conflicts. These tensions and conflicts originate from to a great degree the difficulties to be adapted to the immigrant's milieu. The difficulties faced by the first Turkish generation in Germany and in other western European countries like France were some inadequacies or lack of sufficient qualifications for modern expectations and conditions, especially for a job. Though this is true, "the vanguards of Turkish immigration to industrialized Western countries were the most courageous, progressive and agile individuals of their generations" (Zaptçıoğlu, 2005: 4).

However, the Turks and Kurds from rural areas were those who faced the main and most important problems since they felt the pressure of retaining their Turkishness and Kurdishness as the identity and being a good exemplary Muslim Turk and secular Kurd for their children. Moreover, educational and cultural capacities of these parents were very low and because of this fact they had to live in an isolated familial life (Sayın, 2003: 9). Between these parents who could not learn sufficiently the native language of the European country, and their children who 
were in a European country, many tensions, conflicts, and cultural differences have appeared which is mainly originated from the problems of education since "these children were formed in a mentally, socially, and emotionally very different milieu than their parents." (Atay, 2006: 94) While these parents have the feeling of nostalgia towards the motherland, and to meet this need, watch Turkish TVs, broadcasted on satellites, their children meet with different people via the internet (Atay, 2006: 97). The first generation had both the desire for their children to have a qualified education and the fear for them to be Germanized (Sayın, 2003: 23). There is no any more a place for this fear since the second and third generations call themselves German-Turk/ Kurd, saying that they adopt double identity by getting the citizenship rights of both Turkey and European country. As a conclusion, this fear for the following generations towards the alien culture is getting weakened. Some transformations in the immigrants' lives as well as the desire of the immigrants to have a democratic voice in European scene of politics have a potential to create some changes among the generations. An extensive modernizing process in near future can force more Turkish immigrant population including children to adapt to the integrative mechanisms of the modern system. Cultural insertion and social participation of immigrant's children in modern social life may be seen as a needed tendency which is interpreted as a search for adjustment, adaptation and integration in the host society. This search will be strong in the name of new cultural synthesis, which is the very modern way of expressing the immigrant population's desire in favor of integration in the Western European countries.

\section{References}

Abadan-Unat, N. (1976). "Turkish Migration to Europe (1960-1975). A Balance Sheet of Achievements and Failures" In N. Abadan-Unat (Ed.) Turkish Workers in Europe (1960-1975)- A Socio-Economic Reappraisal, Leiden: E.J. Brill: 1-44.

Abadan-Unat, N. (1978). "Migratory Labour From Mediterranean Countries" In N. Abadan-Unat (ed), Migration and Development-A Study of the Effects on International Labor Migration on Boğazlıyan District, Ankara: MUFFIC IMWOO, Ajans-Türk.

Abadan-Unat, N. (1982). "The effect of International Labor Migration in Women's Roles: The Turkish Case" In Ç. Kağıtçıbaşı (Ed.) Sex Roles, Family and Community in Turkey, Bloomington: Indiana University, Turkish Studies 3.

Abadan-Unat, N. (2002). Bitmeyen Göç-Konuk İşçilikten Ulus-Ötesi Yurttaşlığa, İstanbul: Bilgi Üniversitesi.

Akkaya, Ç. (No date). Yıldız Savaşları. Avrupa, Türkiye ve Avrupa'daki Türkler Üzerine Düşünceler, Türkiye Araştırmalar Merkezi, Köln: Önel-Verlag.

Arayıcı, A. (1998). Avrupa'daki Göçmen İşçilerin ve Çocuklarının Sorunları, İstanbul: Doz.

Association de Solidarité Avec Les Travailleurs Turcs (ASTTU). (1995). Mémoires des Turcs en Alsace, Strasbourg.

Atay, T. (2006). Türkler, Kürtler, Kıbrıslılar. İngiltere'de Türkçe Yaşamak, Ankara: Dipnot yay.

Aydın, Mehmet Zeki and, Yardım, Müşerref. (2008), "Belçika'da İslamofobi" In İsmail Aydoğan and Faruk Yaylacı (eds), I. Uluslararası Avrupalı Türkler Kongresi. "Eğitim ve Kültür”, Cilt-1, Kayseri: Erciyes Üniversitesi. 
Bazin, M. (1994). "L'ouverture des campagnes" In S. Yerasimos (Ed.) Les Turcs, Orient et Occident, Islam et Laïcité, Paris: Éditions Autrement.

Berksü, Ş. (1999). Avrupa Birliğinde Yaşayan Türk İşçilere ve Ailelerine Ortaklık Mevzuatıyla Tanınan Haklar ve Avrupa Toplulukları Adalet Divanı Kararları, Ankara: T.C. Çalışma ve Sosyal Güvenlik Bakanlığı, Yurtdışı İşçi Hizmetleri Genel Müdürlüğü, Yayın No.93.

Bilmen, M. S. (1976). "Educational Problems Encountered by the Children of Turkish Migrant Workers" In N. Abadan-Unat (Ed.) Turkish Workers in Europe (1960-1975). A Socio-Economic Reappraisal, Leiden: E.J. Brill: $.235-252$.

Blanc-Chaléard, M.-C. (2001). Histoire de l'immigration, Paris: Éditions La Découverte.

Boyle, P. et al. (1998). Exploring Contemporary Migration, Longman.

Brabant, J. and Levallois, A.(1995). "La Communauté Turque en Alsace: Les Composantes de l'Insertion”, In M. Anastassiadou (Ed.) Enjeux de L'immigration Turque en Europe, Les Turcs en France et en Europe, Paris: CIEMI-Éditions l'Harmattan.

Buz, Sema (2008), "Federal Almanya'da Göçmenlerin Eğitim Sorunları: Abitur Eğitimlerini Tamamlayan Türkiye Kökenli Gençler Araştırması” In: İsmail Aydoğan ve Faruk Yaylacı (ed.), I. Uluslararası Avrupalı Türkler Kongresi. "Eğitim ve Kültür", Kayseri: Erciyes Ünievrsitesi: 424-437.

Cakirerk, Rana. and West, Johan. (2009),"The Socio-Economic Position of the Turkish Community in Belgium: The Challenge of Integration" In:

Talip Kucukcan and Veyis Gungor (eds.), Turks in Europe. Culture, Identity, Integration, Amsterdam: Turkevi Research Center, pp. 65-78. Camilleri, C. (1996). "Table Ronde (III). L'Immigration Feminine Turque en Europe”, Cahiers D’Études sur la Méditerranée Orientale et le Monde Turco-Iranien, No: 21, janvier-juin.

Carmon, N. (1996). "Immigration and Integration in Post-Industrial Societies: Quantitative and Qualitative Analyses" In N. Carmon (Ed.), Immigration and Integration in Post-Industrial Societies. Theoretical Amalysis and Policy-Related Research, London: MacMillan Press Ltd, 13-62.

Castles, S. and Miller, M. (1993). The Age of Migration. International Population Movements in the Modern World, London: Macmillan Press.

Caymaz, B. (2002). Les mouvements islamiques Turcs à Paris, Paris: L'Harmattan.

De Tapia, S. (2004). “Le Migrations Turques Vers L'Europe: Tendances Recentes”, Conférence-debat 16 Septembre 2003, ORIV (Observatoire Régional de l'Intégration et de la Ville, Alsace), Mai, Strasbourg.

DPT. (2001). Sekizinci Beş Yıllık Kalkınma Planı-Işgücü Piyasası (Yurt Dışında Yaşayan Türkler), Özel İhtisas Komisyonu Raporu, Ankara.

Du Toit, B. M. (1975). "Migration and Population Mobility" In B. M. Du Toit and H. I. Safa (Eds.), Migration and Urbanization. Models and Adaptive Strategies, Chicago: Mouton: 1-15.

Erdoğan, Seçil. (2009), Refugees from Turkey: Reconstruction of Identities in UK" In: Talip Kucukcan and Veyis Gungor (eds.), Turks in Europe. Culture, Identity, Integration, Amsterdam: Turkevi Research Center: 363-379. 
Erpuyan, M. V. (1995). "Entreprises issues de l'immigration Turque en Alsace”, In M. Anastassiadou (Ed.) Enjeux de L'immigration Turque en Europe, Les Turcs en France et en Europe, Paris: CIEMI-Éditions l'Harmattan

Farine, P. (1999). "L’Immigration, Élément Constituant de la Société”, Migrations Société, 11 (64- 65), juilletoctobre.

Fielding, T. (1992). "Migration and culture" In T. Champion and T. Fielding (Eds.) Migration Processes and Patterns, Volume 1. Reserach Progress and Prospects, London: Belhaven Press, pp. 201-212.

Frybès, M. (1992). "France. Un équilibre pragmatique fragile" In D. Lapeyronnie (Ed.) Immigrés en Europe. Politiques Locales d'intégration, Paris: La documentation Française.

Greve, M. (2006). Almanya'da "Hayali Türkiye"nin Müziği, çev. Selin Dingiloğlu, İstanbul Bilgi Üniversitesi yay.

Groc, G. (1995). "Islam: Une insertion par l'absurde?" In M. Anastassiadou (Ed.) Enjeux de L'immigration Turque en Europe, Les Turcs en France et en Europe, Paris: CIEMI-Éditions l'Harmattan.

Gül, N. Z. Ö. (2002). "Doğum Adetlerinin Kültürel Değişim Sürecinde Gaziantep ve Almanya Bağlamında Değerlendirilmesi” In T.C. Kültür Bakanlığı, Yurt Dışında Çalışan Türkler ve Kültürel Değişim, VI. Milletlerarası Türk Halk Kültürü Kongresi, Ankara.

Hanson, R.C. and Simmons, O.G. (1968). "The role of Path. A concept and procedure for studying migration to urban communities", Human Organization, 27, quoted by B. M. Du Toit, "Migration and Population Mobility" In B. M. Du Toit and H. I. Safa (Eds.), Migration and Urbanization. Models and Adaptive Strategies, Chicago: Mouton Publishers.

Helle, P. (2004). Faut-il avoir peur des étrangers? Paris: Éditions de l'Hèbe.

Henslin, J. M. (2001). Sociology. A Down-To-Earth Approach, (5th ed.), Massachusetts: Allyn and Bacon.

Hüküm, P. (1996). "Le Point de Vue d'une Responsable Associative: Qu'en est-il de l'intégration des Femmes Turques en France?”, Cahiers D’Études sur la Méditerranée Orientale et le Monde Turco-Iranien, No:21, janvier-juin.

Irtis-Dabbagh, V. (2003). "Les jeunes originaires de Turquie en France autour de la problématique du marriage", Multitudes. No:6-7-8, Decèmbre.

Kadıŏlu, S. (1990). "AT Ülkelerinde Yaşayan Türk Kadınlarının Sorunları ve Gelecekleri” In Y. Fincancı (Ed.), 30. Yılında Yurt Dışındaki Türkler: Varolma Savaşının Anatomisi, İstanbul: Türkiye Araştırmalar Merkezi-TÜSES Vakfı Konferansı, 24/25 Ekim 1989.

Kağıtçıbaşı, Ç. (1981). Çocuğun Değeri. Türkiye'de Değerler ve Doğurganlık, İstanbul: Boğaziçi Üniversitesi İdari Bilimler Fakültesi

Kağıtçıbaşı, Ç. (1985). "Immigrant Populations in Europe: Problems Viewed from the Sending Country" In I. Başgöz-N. Furniss (Eds.) Turkish Workers in Europe, Bloomington, Indiana: Indiana University Turkish Studies. Pp.103-123.

Kançal, S. (1995). “Émigration: Source d'un Désavantage ou d'un avantage?" In M. Anastassiadou (Ed.) Enjeux de L'immigration Turque en Europe, Les Turcs en France et en Europe, Paris: CIEMI-Éditions l'Harmattan 


\section{Akdeniz Iletișim Dergisi Cultural Integration of Turkish Immigrant Workers' Children into the Host Society An Intergenerational Comparison in the}

Kastoryano, R. (1986). Être Turc en France. Réflexions sur Familles et Comumunauté, Paris:C.I.E.M.I. and L'Harmattan

Kastoryano, R. (1991). "Ethnic Differentiation in France. Turks and Muslims" In M. Kıray (Ed.) Structural Change in Turkish Society, Indiana University.

Kastoryano, R. (1994). "Les émigrés" In S. Yerasimos (Ed.) Les Turcs, Orient et Occident, Islam et Laïcité, Paris: Éditions Autrement

Kastoryano, R. (2000). Kimlik Pazarlığı. Fransa ve Almanya'da Devlet ve Göçmen İlişkileri, çev. Ali Berktay, İstanbul: İletişim yay.

Kaya, A. and Kentel, F. (2005). Euro-Türkler. Türkiye ile Avrupa Birliği Arasında Köprü mü, Engel mi? İstanbul: İstanbul Bilgi Üniversitesi yay.

Kızılocak, G. (1996). Dünden Bugüne Almanya'da Türk Serbest Girişimcileri, Köln:Önel Verlag.

Kleff, H.-G. (1995). "Les Turcs à Berlin Avant et Après la Chute du Mur", In M. Anastassiadou (Ed.) Enjeux de L'immigration Turque en Europe, Les Turcs en France et en Europe, Paris: CIEMI-Éditions l'Harmattan.

Koç, Güneş. (2009) "Turks in Austria and Germany: Stereotypes and Xenophobia” In: Talip Kucukcan and Veyis Gungor (eds.), Turks in Europe. Culture, Identity, Integration, Amsterdam: Turkevi Research Center, pp. 103-128.

Kosinski, L. A. and Prothero, R. M. (Eds.) (1975). People on the Move: Studies on Internal Migration, London: Methuen.

Köksal, S. (1991). "A Ghetto in a Welfare Society. Turks in Rinkeby" In M. Kıray (Ed.) Structural Change in Turkish Society, Indiana University.

Küçükkaraca, N. (1998). Yurtdışından Geri Dönüş-Çalören Örneği, Ankara: Sosyal Hizmet Uzmanları Derneği yay. No:4

Lapeyronnie, D. (1993). L'individu et les minorités. La France et la Grande-Bretagne face à leurs immigrés, Paris: Presses Universitaires de France.

Le Bras, H. (1991). "Demographic Impact of Post-War Migration in Selected OECD Countries" In OECD, Migration. The Demographic Aspects, Paris, pp. 15-27.

Lewis, G. J. (1982). Human Migration. A Geographical Perspective, New York: St. Martin's Press.

Lingayah, S. (1991). A Comparative Study of Mauritian Immigrants in Two European Cities: London and Paris. An investigation into the problems of Adaptation, Éditions de L'Océan Indien.

Macisso, Jr., J. J. (1992). "International Migration: Issues and Research Needs" In C. Goldscheider (Ed.), Migration, Population Structure, and Redistribution Policies, Westview Press, Inc.

Manço, A. (1996). "L'organisation des Familles Turques en Belgique et la place des Femmes", Table Ronde IV. L'Immigration Féminine Turque en France, Cahiers D'Études sur la Méditerranée Orientale et le Monde TurcoIranien, No:21, janvier-juin. 
Martin, P. L. (1996). "Immigration and integration: challenges for the 1990s" In J. Tanton, D. McCormack and J. W. Smith (Eds.), Immigration and the Social Control. The Implosion of Western Societies, Avebury, pp. 27-34.

Mushaben, J. M. (1985). "A Crisis of Culture: Isolation and Integration Among Turkish Guestworkers in the German Federal Republic" In İ. Başgöz-N. Furniss (Eds.) Turkish Workers in Europe, Bloomington, Indiana: Indiana University Turkish Studies, pp. 125-150.

Mutlu, H. and Sancar, A. (2000), "Stratégies identitaires collectives: Dynamiques de restructuration sociale des migrants originaires de Turquie en Suisse = Collective identity strategies: social restructuration dynamics of the migrants coming from Turkey in Switzerland, CEMOTI. Cahiers d'études sur la Méditerranée orientale et le monde turco-iranien, No. 30, pp. 223-251.

Naïr, S. (1990). “L’Europe et ses immigrés”, L’Événement Européen. Initiative et débat, (Dossier: L’Europe et Ses Immigrés), Octobre, 11, Seuil.

OECD Secretariat, (1991). "Evolution of Fertility of Foreigners and Nationals in OECD Countries", In OECD, Migration. The Demographic Aspects, Paris.

Öztürk, A. O. (2002). "Resitatif Almanya Türkülerinin Üslubu Üzerine” In T.C. Kültür Bakanlığı, Yurt Dışında Çalışan Türkler ve Kültürel Değişim, VI. Milletlerarası Türk Halk Kültürü Kongresi, Ankara.

Öztürk, K. (1995). "Les Turcs dans la confection à Paris” In M. Anastassiadou (Ed.), Enjeux de L'immigration Turque en Europe, Les Turcs en France et en Europe, Paris: CIEMI-Éditions l'Harmattan.

Paine, S. (1974). Exporting Workers. The Turkish Case, Cambridge University Press.

Parnwell, M. (1993). Population Movements and the Third World, London: Routledge.

Pieters, J. N. (2005). "Göç Sürecinde İslâm: Minaresiz Camiler" In A. Öncü and P. Weyland (Eds.) Mekân, Kültür, İktidar. Küreselleşen Kentlerde Yeni Kimlikler, çev. Leyla Şimşek-Nilgün Uygun, İstanbul: Iletişim yay.

Pooley, C. G. and Whyte, I. D. (1991). "Introduction. Approaches to the study of migration and social change" In C. G. Pooley and I. D. Whyte (Eds.), Migrants, Emigrants and Immigrants. A Social history of migration, London: Routledge.

Republic of Turkey, Ministry of Labor and Security, Dış Illişkiler ve Yurtdışı İşçi Hizmetleri Genel Müdürlüğü, (2004). 2003 Yılı Raporu. Yurtdışındaki Vatandaşlarımıza Illişkin Gelişmeler ve Sayısal Bilgiler, Ankara.

Richmond, A. H. (1988). "Socio-cultural adaptation and conflict in immigrant-receiving countries" In C. Stahl (Ed.) International Migration Today. Volume 2: Emerging issues, Paris: Unesco/ University Western Australia.

Salom, G. (1989). “Propos sur L’Exil Turc. Comment Defaire Les Valises?”, Migrants-Formation, №:76, Mars.

Salom, G. (1995). "Les femmes et le projet migratoire Familial Turc en France" In M. Anastassiadou (Ed.) Enjeux de L'immigration Turque en Europe, Les Turcs en France et en Europe, Paris: CIEMI-Éditions I'Harmattan.

Sayın, Ö. (1975). Les Travailleurs Immigres Turcs en Europe, Unpublished Doctorate Thesis, Université des Sciences et Techniques de Lille.

Sayın, Ö. (2003). "Almanya'da Yaşam Deneyimi Olan Türk Gençleri”, Sosyoloji Dergisi, No.10-11, pp.5-26. 
Schittenhelm, Karin. (2011), "Ikinci Kuşağın Kariyerinde Statü Geçişleri” In: Arnd-Michael Nohl et all, Göç ve Kültürel Sermaye. Türkiye, Almanya, Kanada ve Büyük Britanya'da Yüksek Vasıflı Göçmenler, çev. Türkis Noyan, İstanbul: Kitapyayınevi, ss. 53-72.

Schnapper, D. (1991). La France de l'intégration. Sociologie de la nation en 1990, Paris: Éditions Gallimard.

Schultze, G. (1995). "Première et Deuxième Génération de Migrants Turcs en RFA: Mobilité Professionelle et son incidence sur le processus d'intégration" In M. Anastassiadou (Ed.) Enjeux de L'immigration Turque en Europe, Les Turcs en France et en Europe, Paris: CIEMI-Éditions I'Harmattan

Sertel, Y. (1987). Nord-Sud: Crise et Immigration (Le Cas Turc), Paris: Éditions Publisud.

Sinha, W. N. P. and Ataullah, M. D. (1987). Migration. An Interdisciplinary Approach, Delhi: Sema Publications.

Somersan, S. (2004). Sosyal Bilimlerde Etnisite ve Irk, İstanbul: İstanbul Bilgi Üniversitesi yay.

Stillwell, J. and Congdon, P. (1991) "Migration modelling: concepts and contents" In J. Stillwell and P. Congdon (Eds.) Migration Models. Macro and Micro Approaches, London: Belhaves Press.

Stolnitz, G. J. (1978). "International Migration Policies: Some Demographic and Economic Contexts" In W. H. McNeil and R. S. Adams (Eds.), Human Migration. Patterns and Policies, Bloomington, Indiana University Press, pp 307-330.

Şen, F. (1990). "Yurt Dışındaki Türk Varlığı: Sorunlar, Beklentiler" In Y. Fincancı (Ed.), 30. Yılında Yurt Dışındaki Türkler: Varolma Savaşının Anatomisi, Türkiye Araştırmalar Merkezi-TÜSES Vakfı Konferansı, 24/25 Ekim 1989, İstanbul.

Şen, F. and Koray, S. (1993). Türkiye'den Avrupa Topluluğu'na Göç Hareketleri, Türkiye Araştırmalar Merkezi, Köln: Önel-Verlag

Şen, F. et al. (1996). Almanya'da Ayrımcılık. Federal Alman iş Piyasasında Türklere Yönelik Ayrımcılık, Köln: Önel yayınevi.

Tabouret-Keller, A. and Konuk, M. (1996). "Un Aperçu de la Situation Linguistique Des Turcs en Alsace. Autournant des années 90, trois études de cas et un Témoignage", Avancées, L'integration des Étrangers dans L'Europe contemporaine, Chantiers de recherche, Séminaire 1994/1995, No:3, Presses Universtaires de Strasbourg.

Taïeb, E. (1998). Immigrés: l'effet Générations. Rejet, Assimilation, Intégration d'hier à aujourd'hui, Paris: Les Éditions de l'Atelier.

Tribalat, M. (1995). Faire France. Une grande enquete sur les immigrés et leurs enfants, Paris: Éditions la Découverte.

Unbehaun, H. (1995). “La Population Turque à Bamber” In M. Anastassiadou (Ed.) Enjeux de L'immigration Turque en Europe, Les Turcs en France et en Europe, Paris: CIEMI-Éditions l'Harmattan

United Nations (UN) (1994). International Migration: Regional Processes and Responses, Economic Studies, No. 7, pp.53-55. 
94 Akdeniz Iletișisim Dergisi

Kemal İnal

Vassaf, G. (2002). Daha Sesimizi Duyurmadık. Almanya'da Türk İşçi Çocukları, İstanbul: İstanbul Bilgi Üniversitesi Yayınları.

Verbunt, G. (1977). "Une culture pour le folklore ou pour la lutte?" Culture Immigreé. Intégration ou résistance: les immigrés parlent de leurs tentatives d'expression culturelle, No:11, Novembre, Autrement, Paris.

Wilpert, C. (1996). “Table Ronde IV. L'Immigration Féminine Turque en France”, Cahiers D’Études sur la Méditerranée Orientale et le Monde Turco-Iranien, No. 21, janvier-juin.

Yılmaz, S. (2001). Fransa'da Türkçe Öğretmenlik Klavuzu, Bourg en Bresse: CeFReSS.

Zaptçıŏlu, D. (2005). "Öncüler Nesli” In M. Richter (Ed.) Geldiler ve Kaldılar... Almanya Türkleri'nin Yaşam Öyküleri, çev. Mutlu Çomak-Özbatır, İstanbul: İstanbul Bilgi Üniversitesi, pp. 1-15.

Zarif, F. et al. (1995). İkibinli Yıllarda Almanya'da Türkler, Türkiye Araştırmalar Merkezi, Ankara: Önel. 